Senad Jasarević*

\title{
SERBIAN ANTI-DISCRIMINATION LABOUR LEGISLATION ${ }^{1}$
}

This paper presents Serbian anti-discrimination legislation in the field of labour, comprising five acts passed after the year 2006, including the Labour Code. The said legislation was drafted along the lines of the EU document on equality. This paper also summarises the content of Serbian anti-discrimination acts and analyses certain solutions related to the EU and other international standards.

\section{Introduction}

In the past ten years, Serbia has made a serious effort to regulate protection of citizens equality, which also included protection from discrimination at work. Following the Labour Code enactment in 2005 (as the first instance of a more particularised regulation prohibiting discrimination $)^{2}$, a set of anti-discrimination acts was also adopted, which concurrently improved the regulations related to the field of work. Among them were the Act on Prevention of Discrimination Against Persons with Disabilities of 2006, Anti-Discrimination Act of 2009, Gender Equality Act of 2009, and the Act on Prevention of Harassment at Work of $2010^{3}$.

* Professor, University of Novi Sad, Faculty of Law, Labour law and social security chair, 21000, Novi Sad, Trg Dositeja Obradovića 1, Serbia.

1 This paper presents results of the research project of the Faculty of Law in Novi Sad: Biomedicine, environmental protection and the law (No. 179079), funded by the Ministry of Science and Technological Development of Serbia.

2 The Code was published in the Official Gazette of the Republic of Serbia (RS), No. 24/2005, 61/2005, 54/2009, 32/2013, 74/2014.

3 Mentioned laws were published in: 1) Official Gazette of the RS, No. 33/2006; 2) Official Gazette of the RS, No. 22/2009; 3) Official Gazette of the RS, No. 104/2009; 4) Official Gazette of the RS, No. 36/2010, 5) Official Gazette of the RS, No. 24/2005, 61/2005, 54/2009. 
These regulations incorporated the model of equality protection in place in the European Union (EU). After the year 2000, Serbia began its accession to the European Union and in 2012 it acquired the status of a membership candidate ${ }^{4}$.

Legislation on equality of employees in the EU is considered to be among the most developed in the world. It makes more than a half of the EU labour law standards. In addition, these regulations contain ample documents on gender equality. The provisions on equality of employees are present in many of the EU acts, from the most important documents of the Union, such as The Treaty on European Union and the Treaty on the Functioning of the EU of $2010^{5}$, through the Charter on the Fundamental Rights of the EU of $2000^{6}$, the European Union Community Charter of the Fundamental Social Rights of Workers of $1989^{7}$, including particularised legislation (regulations, directives) ${ }^{8}$.

The present concept of protection of equality of citizens in the EU is based on the idea of transformative - integrative practice aiming to establish full social and economic equality of all EU citizens, and eliminate the so-called systemic inequalities. This entails not only challenging discrimination at work, but also eliminating the inequalities rooted in social mechanisms and structures that lead to inequalities in practices.

By adopting the above-mentioned anti-discrimination acts, Serbia has made a big positive step towards the EU standards. Still, we cannot talk about "har-

${ }^{4}$ More about the process of Serbia's accession to the EU can be seen in: B. Budimir, V. Međak, Serbia's EU accession, ISAC Fund, Belgrade 2010, http://www.isac-fund.org/download/Pridruzivanje-Srbije- EU.pdf; Office of the Government of the Republic of Serbia for European integration, http://www.seio.gov.rs/početna.1.html

5 The Treaties were published in the Official Journal (OJ), C 83, of 30 March 2010. See: Treaty on European Union - item 3 of the Preamble, Art. 2, 3, 9. Treaty on the Functioning of the European Union - Art. 8, 10, 153, 157 - items 1-3, 4 .

6 The entire third chapter of the Charter is dedicated to equality (Articles 20-26). The Charter was republished in the same bulletin as previously mentioned agreements (2010).

7 From 9 December 1989. See item 16. The Charter is available at: http://www.aedh. eu/plugins/fckeditor/userfiles/file/Conventions\%20internationales/Community_Charter_of_the_Fundamental_Social_Rights_of_Workers.pdf.

8 There are numerous documents that were being brought in 1970s and on, but they will not be listed in this paper. Only those more recent and most important ones will be mentioned, such as: 1) Council Directive 2000/78/EC establishing a general framework for equal treatment in employment and occupation - 27 November 2000; 2) Council Directive 2000/43/EC of 29 June 2000 implementing the principle of equal treatment between persons irrespective of racial or ethnic origin; 3) Directive on the implementation of the principle of equal opportunities and equal treatment of men and women in matters of employment and occupation (recast), of 5 July 2006 (which integrates earlier directives on gender equality, No. 75/117/EEC, 76/207/EEC and 2002/73/EC, 86/378/EEC, 96/97/ $\mathrm{EC}, 97 / 80 / \mathrm{EC}, 98 / 52 / \mathrm{EC})$. According to the above given sequence, these documents were published in: 1) OJ L 303, 02/12/2000; 2) OJ L 180, 19/07/2000, 3) OJ 204/23, 05/7/2006.

9 See: B. Hepple, B. Veneziani, The Transformation of Labour Law in Europe, Oxford and Portland, Oregon, 2009, p. 129 and 158; S. Jašarević, Protection of equality of employees in European Union legislation, Law Journal 2010, No. 3, University of Novi Sad, Novi Sad, p. 258. 
monisation" with the EU practices. The biggest problem is the application of regulations. Many solutions of Serbian anti-discrimination law have not yet been implemented (e.g. in the field of non-discrimination, recruitment and promotion of "vulnerable" categories in society, greater representation of women at leadership positions, reconciliation between work and family life, recognition of home work, access to work for disabled persons, mobbing), thus leaving room for speculations as to when these issues will be resolved. The reasons for this are rooted in the society itself and cannot be changed overnight. These are for example: specific mentality (formed under the influence of socialism), the state's unwillingness to implement legislation consistently, general public's non-compliance with the existing regulations, formalism in law implementation, ineffective judicial protection, unwillingness to accept different standards of conduct at work, prejudices and stereotypes, social mechanisms that diminish discrimination (e.g. lack of participation of "vulnerable" groups in the field of education, patriarchal approach).

\section{Serbian legislation on prohibition of discrimination at work}

Art. 21 of the Constitution of the Republic of Serbia prohibits all forms of discrimination on any grounds (except for the affirmative action) ${ }^{10}$. Also, in 2003 Serbia became a member of the Council of Europe and ratified the European Convention for the Protection of Human Rights and Fundamental Freedoms (ECHR) of 1950, along with the accompanying protocols ${ }^{11}$, and thus took on the obligation to comply with the prohibition of discrimination under Art. 14 of the Document and the Protocol No. $12^{12}$.

In particular, prohibition of discrimination at work is governed by a separate head in the Labour Code as well as by the aforementioned anti-discrimination regulations along with some other acts related to the field of work ${ }^{13}$. We will make

10 The Constitution was published in Official Gazette of the RS, No. 98/2006.

11 Official Journal of the FRY, International Treaties, No. 9/2003.

12 See Handbook on European non-discrimination legislation, The European Union Agency for Fundamental Rights, 2010, the Council of Europe, 2010, p. 12 and 58.

13 For example, The Act on Employment and Unemployment Insurance (Official Gazette of the RS, No. 36/2009, 88/2010), in Art. 5 provide the principle of prohibition of discrimination and the principle of gender equality; Act on Vocational Rehabilitation and Employment of Disabled Persons (Official Gazette of the RS, No. 36/2009) in Art. 2 establishes the principle of prohibition of discrimination of persons with disabilities and the principle of gender equality; The Act on Civil Servants (Official Gazette of the RS, No. 79/2005, 81/2005, 83/2005, 64/2007, 67/2007, $116 / 2008,104 / 2009$ ) guarantees equal access to employment (Article 9) and equal legal protection. Act on Health Protection (Official Gazette of the RS, No. No. 107/2005, 72/2009, 88/2010, 99/2010, $57 / 2011$ ), Art. 20 sets forth the ban on discrimination in the provision of health services. 
a brief overview of these regulations and the most important solutions related to non-discrimination.

In the Labour Code (LC), the entire fifth head (Art. 18-23) is dedicated to prohibition of discrimination. In addition to the general prohibition of discrimination, it deals with the following issues: bases of discrimination, the concept of direct and indirect discrimination, fields of discrimination (from the conditions for recruitment, education, promotion, up to termination of employment), prohibition and the concept of harassment and sexual harassment, justifiable exceptions, availability of affirmative action, possibility of initiating court proceedings for reimbursement of damages ${ }^{14}$.

The Anti Discrimination Act (hereinafter ADA) of 2009 - is the governing act in this field, although it was enacted after some of the mentioned acts. This Act regulates: general prohibition of discrimination, forms and cases of discrimination, and methods of protection against discrimination. It also establishes the Commissioner for Protection of Equality (CPE as an autonomous and independent government authority assigned to ensure protection against discrimination. This act is very comprehensive. It establishes the general prohibition of discrimination and defines its forms, regulates specific cases of discrimination (discrimination in proceedings before public authorities, in the field of labour, provision of public services and use of facilities and sites, discrimination based on religion, in education and training, discrimination based on gender, sexual orientation, discrimination of children, age discrimination, discrimination of ethnic minorities, discrimination based on political and trade union membership, discrimination of persons with disabilities, discrimination based on the state of health). It also regulates the procedure for the protection of rights before the $\mathrm{CPE}$ and before the court, which is characterised by special rules different from the civil procedure (urgency, admissibility of review in all cases, specific requirements for the plaintiff, the burden of proof - transferred to the defendant, option of imposing a temporary measure), possibility of taking action by other parties (the Commissioner or organisations involved with the protection of human rights - implying the consent of the affected party), the existence of "voluntary examiners", penalties and sanctions (albeit very modest ${ }^{15}$.

The Act on Prevention of Discrimination against Persons with Disabilities, of 2006, (hereinafter referred to APDAPD), was the first specific anti-discrimination act in Serbia. It was adopted in 2006. The Act is based on modern "social concept" of persons with disabilities, which means that the measures envisioned focus on elimination of discrimination by greater inclusion of these persons into

14 The Labour Code has been changed in July this year. As for the part related to discrimination, there are no major changes, except in Art. 23, item 2, which introduces the burden of proving on the part of the respondent (it was not provided previously).

${ }_{15} \mathrm{Up}$ to 850 EUR for legal entities. 
society and active work ${ }^{16}$. Similarly to the previously mentioned Act, it postulates general prohibition of discrimination and regulates various forms of discrimination (direct and indirect discrimination, violation of the principle of equal rights and obligations, severe forms of discrimination), establishes specific instances of discrimination (in proceedings before public authorities, in relation to associations, provision of services and use of facilities and sites, health services, care and education, in employment and labour relations, in transport, marriage and family relations). It also lays down the measures aimed at promoting equality of persons with disabilities (establishment of support associations, creating accessible environment, integration into mainstream education, access to information, etc.). In addition, it makes provisions for enhancement of equality of persons with disabilities (greater possibilities of initiating court proceedings - e.g. by the accompanying persons, claims of the plaintiff are adjusted to discrimination disputes; possibility of revision), and finally, sets forth the penalties and sanctions (regrettably, modest fines).

The Act on professional rehabilitation and employment of persons with disabilities of 2009 should help resolve the problem of employment of persons with disabilities. Under this Act, persons with disabilities may be employed under special conditions (implying adjustment of business or work place). One important novelty is the obligation of every employer with more than 20 employees to employ a certain number of persons with disabilities (Art. 24). If he fails to comply, the employer is bound to pay a penalty equal to the triple minimum wage determined by the labour regulations for each person he missed to hire.

The Act on Gender Equality, of 2009 (hereinafter: AGE) pays great attention to improving the position of the sexes (mostly women) in the field of labour. The second part of the Act is entitled "Employment, social and health care", Art. 11-26. It can be said that its "structural approach" aimed at eliminating discrimination makes the difference. Namely, in addition to the general prohibition of discrimination (and harassment and sexual harassment), the Act contains a number of concrete measures and mechanisms conducive to eliminating inequality (e.g., obligatory Plans for elimination or mitigation of unequal gender representation, preparation of annual reports on the implementation of the Plan, 30\% quotas for employment of both sexes in public bodies, compulsory enforcement of measures of affirmative action; an obligation of the employer to implement gender representation that reflects the gender structure of employees in every phase of professional development, possibility of establishing special state funds for

${ }^{16}$ According to Art. 3 of the Act, persons with disabilities include: “... people with congenital or acquired physical, sensory, intellectual or emotional disability that, due to social or other barriers, are not able or have limited opportunities to engage in social activities at the same level as others, regardless of whether they can engage in those activities with the use of technical aids or support services". 
hiring underrepresented gender, etc.). So called "measures for reconciliation of professional and family life" are also provided, so that, for example, institutions of social and health services are obliged to adapt their work organisation and working hours to the needs of customers - i.e. employees (Art. 25 of the Act). However, this brings moderate effects as, for the most part, the Act has remained a "dead letter" so far.

The Act on the Prevention of Harassment at Work, of 2010 indirectly belongs to the set of anti-discrimination acts. Namely, despite the fact that this act deals with discrimination issues indirectly, save Art. 3 where it approaches discrimination directly by stipulating that the protection covers cases of sexual harassment as well), it actually regulates "mobbing" 17 . By implicating that the environment that tolerates mobbing stimulates discrimination, prohibition of mobbing will have a positive influence on protection against discrimination.

\section{Protection against discrimination at work in Serbia}

Based on the concept of this article, thorough analysis of the subject matter will be substituted by appropriate basic questions and specific provisions.

The concept of discrimination in these regulations meets international and European standards. For example, according to the Anti Discrimination Act (ADA), Art. 2, the terms "discrimination" and "discriminatory treatment" shall be used to designate any unwarranted discrimination or unequal treatment, that is to say, omission (exclusion, limitation or preferential treatment) in relation to individuals or groups, as well as members of their families or persons close to them, be it overt or covert, on the grounds of race, skin colour, ancestors, citizenship, national affiliation or ethnic origin, language, religious or political beliefs, gender, gender identity, sexual orientation, financial position, birth, genetic characteristics, health, disability, marital and family status, previous convictions, age, appearance, membership of political, trade union and other organisations and other real or presumed personal characteristics.

The grounds on which discrimination is prohibited are similar to those found in international standards. For example, the Constitution prohibits any direct or indirect discrimination "... on any grounds, in particular race, sex, nationality, social origin, birth, religion, political or other opinion, property status, culture, language, age, or mental or physical disability" (Art. 21). While Labour Act stip-

17 The Act defines all that constitutes mobbing, possible performers, processes of internal (mediation) and judicial protection (including certain specific characteristics, similar to those in already mentioned acts, e.g. urgency, specific plaintiff claims, the burden of proving, provisional measures). Fines are slightly higher than those in previously mentioned acts, up to 34,000 EUR (400 000 dinars) for legal entities. 
ulates twenty grounds for discrimination ${ }^{18}$, the ADA provides twenty five. This list is not "closed", as it envisages an "open clause on discrimination", so that the number of bases of discrimination is in fact indefinite. The Constitution, for example, prohibits discrimination based on any grounds. The LC says that discrimination may be based on any other personal quality, and in ADA: "presumed personal characteristics". This solution is very important in the field of labour relations, where besides the usual basis of discrimination many specific reasons for discrimination may occur, such as work experience, years of service, personal status, position, marital status (married, divorced, not married), birth outside of marriage, family responsibilities (number of children, taking care of incapacitated family members), the intention to have offspring, whether the person is a smoker or not or drinks alcohol, suffers from obesity or high blood pressure, it could be as well membership of an association or affiliation to a specific movement, place of residence, dressing habits ${ }^{19}$.

Forms of discrimination also correspond to current comparative legal standards. In addition to the usual distinction between direct and indirect discrimination, other forms of discrimination found in international documents are mentioned in Serbian regulations as well. For example, besides already mentioned forms of direct and indirect discrimination, ADA provides a stipulation on "severe forms of discrimination" (Art. 13), such as repeated discrimination, "extended" discrimination (discrimination that lasts) or "cross-discrimination" (discrimination on several basis). In terms of the Act on Prevention of Discrimination against Persons with Disabilities, Art. 26 (the part related to discrimination at work), "particularly gross form of discrimination based on disability is disturbing, insulting and belittling of the employee with a disability by the employer or immediate superiors in the work process, because of his/her disability". The same Act also prohibits "transferred discrimination" (in terms of Art. 21, par. 1: "It is forbidden to discriminate against employment and use of labour rights of: 1 . person with disability seeking employment; 2. person assisting a disabled person seeking employment, 3. employed persons with disabilities; 4 . employed escort of the person with disabilities...".

18 "Both direct and indirect discriminations are prohibited against persons seeking employment and employees in respect to their sex, origin, language, race, colour of skin, age, pregnancy, health status or disability, nationality, religion, marital status, familial commitments, sexual orientation, political or other belief, social background, financial status, membership in political organisations, trade unions or any other personal quality" (Art. 18 of the LC).

19 See for more: Equality at work, Tackling the Challenges, International Labour Conference, ILO, 2007, Geneva, p. 15, 45-53; I. Grgurev, Discrimination on grounds that are not explicitly prohibited in the employment code, Labor Code, Zagreb 2007, No. 3, p. 42; R. Doting, Can boss insist on healthy habits?, Christian Science Monitor, January 11, 2006 edition: http://www.csmonitor.com/2006/0111/p15s01-ussc.html/; U. Furi-Perry, Butting In: Employers penalise Smokers and Overweight Workers, 8 November 2004, Employer \# Crossing, http://www.lawcrossing.com/article/416/Butting-In-Employers-Penalise-Smokers-and-Overweight-Workers/\#. 
The definitions of direct and indirect discrimination are more or less taken from the EU standards. For example, the Labour Code, Art. 19: "(1) Direct discrimination, pursuant to this law, shall be any action caused by some of the grounds referred to in Article 18 of this law that puts a person seeking employment or employee in a less favourable situation than other persons in the same or similar situation" 20. "(2) Indirect discrimination, pursuant to this law, shall be recognised in case an apparently neutral provision, criterion or practice puts or would put a person seeking employment or employee in a less favourable situation than other persons, due to a certain quality, status, belief or position of such person referred to in Article 18 of this law" ${ }^{\prime 2}$.

Following the example of EU legislation, prohibition of discrimination includes protection against harassment and sexual harassment ${ }^{22}$. In terms of Art. 21 of the LC: “... (2) Harassment, pursuant to this law, is any unwanted behaviour resulting from some of the grounds referred to in Article 18 of this law aimed at or representing a violation of dignity of a person seeking employment or employee, causing fear or breeding adverse, humiliating or insulting environment. (3) Sexual harassment, pursuant to this law, is any verbal, non-verbal or physical behaviour aimed at or representing a violation of dignity of a person seeking employment or employee in the area of sexual life, causing fear or breeding adverse, humiliating or insulting environment"23.

The forms of discrimination are also defined in conformity to the recent legal standards in this area. For example, in terms of Art. 5 of ADA: "The forms of discrimination are direct and indirect discrimination, as well as violation of the principle of equal rights and obligations, calling to account, associating for the purpose of exercising discrimination, hate speech and disturbing and humiliating treatment".

20 This implies an assumed basis for discrimination, as discussed previously.

${ }^{21}$ For example, according to Art. 2, Para 2 of the EC Directive No. 78/2000, of 2000th years, "(a) direct discrimination shall be taken to occur where one person is treated less favourably than another is, has been or would be treated in a comparable situation, on any of the grounds referred to in Article 1; (b) indirect discrimination shall be taken to occur where an apparently neutral provision, criterion or practice would put persons having a particular religion or belief, a particular disability, a particular age, or a particular sexual orientation at a particular disadvantage compared with other persons unless: (i) that provision, criterion or practice is objectively justified by a legitimate aim and the means of achieving that aim are appropriate and necessary...". The definition is similar to the definition found in Art. 2 of the Directive No. 54/2006.

22 Harassment is prohibited by all EU directives on discrimination released after the year 2000, while Directive 2006/54/EC prohibits sexual harassment as well.

23 This definition of harassment corresponds to the definition of harassment under Art. 2, item 3 of the EU Directive No. 78/2000. The term sexual harassment was taken from the Directive on Gender Equality of 2006. (Article 2, item 3) that originates from former Directive No. 2002/73, whereby the concept of sexual harassment was introduced into the EU law. However, there are tiny differences arising from translation, that slightly change the meaning of the definition. 
Similarly to EU law, reasonable exceptions to the prohibition of discrimination are set as well, and they can be applied when different treatment is justified or necessary. For example, in terms of Art. 22, paragraph 1 LC: (1) "Differentiation, exclusion or prioritisation for a certain job shall not be considered discriminating when the nature of the work is such or the work is done under such circumstances that relating to some of the grounds referred to in Article 18 of this law represent the true and decisive requirement for the performance of such a job, and that the purpose aimed at is justified". In terms of Art. 14 of the ADA (subtitle: Special measures): "Measures introduced for the purpose of achieving full equality, protection and progress of an individual or a group of persons in an unequal position shall not be considered to constitute discrimination" 24 .

Justifiable exceptions include measures of affirmative action. In Art. 22, paragraph 2 of the LC it is stipulated as follows: "Provisions of this law, the general document and labour contract relating to special protection and assistance to certain categories of employees, particularly those relating to protection of disabled persons, women on maternity leave and absence from work for childcare, special childcare and provisions relating to special rights of parents, adoptive parents, guardians and foster parents - shall not be interpreted as discrimination".

"Quotas" were introduced as one of the measures of affirmative action. Pursuant to Art. 14 of the AGE (subtitle: "Equal access to jobs and positions"), "If representation of the less represented gender in each organisational unit at the level of managerial positions, management board and supervision is less than $30 \%$, the public authorities have to implement affirmative action in accordance with the Law on Civil Servants and the Law on State Administration".

"Prohibition of victimisation" (retaliation or repression arising from initiation of the proceedings against discrimination or addressing discrimination) is a precondition that has to be fulfilled in order to have effective prohibition of discrimination. Victims of discrimination who bring unequal treatment into open are often harassed in many different ways (for example: current discrimination is more intensified, discriminated person is avoided by other employees, the person is moved to another, "worse" job or harassed or mobbed in order to quit the job, or even dismissed from job on the false grounds or declared redundant). Prohibition of victimisation was first introduced by EU documents (Art. 11 of the Directive No.: 78/2000, Art. 9 of the Directive No. 43/2000, Art. 24 of the Directive

${ }^{24}$ For example, according to the Directive No. 78/2000 (Article 2, item 5.), of 2000, the prohibition of discrimination shall not apply to measures laid down by the national legislation which are necessary in a democratic society for protection of public safety, public order, prevention of crime, and for protection of health, rights and freedoms of others. Pursuant to the Directive on Gender Equality of 2006 (Article 2), there is no discrimination “... if such provision, criterion or practice is objectively justified by a legitimate goal and if the means for achieving it is appropriate and necessary". 
No. 54/2006 $)^{25}$, and soon spread to the national legislation. According to Art. 8 of the AGE: "No one shall bear any consequence as a witness to or victim of discrimination based on gender when testifying before the competent authority, or if warning the public of the occurrence of discrimination". According to Article 20 of the same Law, initiation of proceedings by the employee for discrimination based on sex cannot be considered a justifiable reason for termination of work agreement, i.e. termination of employment and other (contractual) involvements related to his/her present work, nor it can be considered a reasonable ground for declaring the employee redundant. Art. 9 of the ADA provides "ban on calling to liability": "Discrimination exists if a person or group of persons unjustly receives or would receive worse treatment than others, solely or mainly because they seek or intend to seek protection from discrimination, or because they are offering or intending to offer evidence of discriminatory treatment".

The very proof of discrimination is a major problem in practice. Since discrimination is generally not openly apparent, statistical data or other indicators are often used as evidence in comparative practices. Also, the "test cases" or "voluntary examiners" are used in practice. The Law on Prohibition of Discrimination (Art. 46) refers to "voluntary examiners": “... (3) A person who has deliberately exposed him/herself to discriminatory treatment intending to directly verify the application of the regulations pertaining to prohibition of discrimination in a particular case may initiate a lawsuit referred to in Article 43 items 1, 2, 3 and 5 of this Law... (5) If the person referred to in paragraph 3 of this Article has not initiated a lawsuit, a court may hear him/her as a witness. (6) The person referred to in paragraph 3 of this Article may not be claimed to share any responsibility for the damage resulting from a discriminatory act". In order to provide relevant statistical data, the AGE provides that the employer is obliged to keep records of the gender structure of employees, in accordance with the relevant labour law and to make the data available to authorised labour inspection and the body appointed to observe the implementation of gender equality (Art. 12).

In evidentiary proceedings, the burden of proof is of the highest importance. It is extremely difficult for victims of discrimination to prove it in Court, as it is applied in a secretive, sneaky way, or witnesses to discrimination are reluctant to confirm it. To facilitate detection, under the influence of American law, the EU has introduced a "split burden of proof" and "burden of proof on the employer". The Directive No. 97/80/EC on the burden of proof in cases of discrimination

${ }_{25}$ For example, Article 24 of the Directive 54/2006, subtitle: Victimisation, provides the following: "Member States shall introduce into their national legal systems such measures as are necessary to protect employees, including those who are employees' representatives provided for by national laws and/or practices, against dismissal or other adverse treatment by the employer as a reaction to a complaint within the undertaking or to any legal proceedings aimed at enforcing compliance with the principle of equal treatment". 
based on sex was introduced in 1997. It stipulates that after concluding the prima facie discrimination the burden of proof shall be transferred to the respondent (in the field of labour - the employer). This solution was subsequently adopted in all EU anti-discrimination documents ${ }^{26}$, as well as in most recent national legislations on prohibition of discrimination that were made under the influence of EU law. In terms of Art. 45 of Serbian ADA: "If the Court establishes that a direct act of discrimination has been committed, or if that fact is undisputed by the parties to a lawsuit, the defendant may not be relieved of responsibility by supplying evidence that he/she is not guilty".

It became obvious that anti-discrimination laws without sanctions are hardly sustainable. According to the EU regulations, sanctions for discrimination at work should be: effective, proportionate, convincing ${ }^{27}$. Sanctions for discrimination in Serbian law can be divided into: monetary and non-monetary. According to Art. 43 ADA, through a lawsuit the plaintiff may demand: " 1 . imposing a ban on an activity that poses a threat of discrimination, a ban on proceeding with a discriminatory activity, or a ban on repeating a discriminatory activity; 2 . that the court should establish that the defendant has treated the plaintiff or another party in a discriminatory manner; 3 . taking steps to redress the consequences of discriminatory treatment; 4 . compensation for material and non-material damage; 5 . that the decision passed on any of the lawsuits referred to in items 1-4 of this Article be published". Monetary fines under this law range from 10,000 to 100,000 dinars (about EUR 85 to 850), for legal entities, entrepreneurs, public officials, and physical persons". (Art. 51 of the Law) ${ }^{28}$. Although punitive sanctions are anticipated

${ }^{26}$ For example, Art. 10 of the Directive No. 78/2000 says: "Member States shall take such measures as are necessary, in accordance with their national judicial systems, To ensure that, when persons who consider themselves wronged because the principle of equal treatment has not been applied to them establish, before a court or other competent authority, facts from which it may be presumed that there has been direct or indirect discrimination, it shall be for the respondent to prove that there has been no breach of the principle of equal treatment". See also: Art. 19 of the said Directive 54/2006.

27 "Member States shall lay down the rules on sanctions applicable to infringements of the national provisions adopted Pursuant to this Directive and shall take all measures necessary to Ensure that they are applied. The sanctions, which may comprise the payment of compensation to the victim, must be effective, proportionate and dissuasive. Member States shall notify those provisions to the Commission by 2 December 2003 at the latest and shall notify it without delay of any subsequent amendment affecting them". Art. 17 of the Directive 78/2000.

${ }_{28}$ We believe that such a regulated financial sanctions do not fit into the concept of EU discrimination law, because such penalties are not dissuasive enough, having in mind the low fine. See ECJ, judgment of 25 April 2013, Case C-81/12, Assoçiatia Accept v Consiliul Naţional pentru Combaterea Discriminării, para. 64). The Court (Third Chamber) hereby rules: “...3. Article 17 of Directive 2000/78 must be interpreted as meaning that it precludes national rules by virtue of which, where there is a finding of discrimination on grounds of sexual orientation within the meaning of that directive, it is possible only to impose a warning such as that at issue in the main proceedings where such a finding is made after the expiry of a limitation period of six months from the date on 
as well, they are rarely enforced. Art. 137 of the Criminal Code of the Republic of Serbia, $2005^{29}$ provides: "(2) Whoever, by force, threat, or other improper means inflicts severe pain or suffering on another person in order to obtain from him/her or any third person a confession, statement or other information, or to intimidate $\mathrm{him} / \mathrm{her}$ or a third person, or inflicts an illegal punishment, or does so for any other reason based on discrimination of any kind, shall be punished with imprisonment from six months to five years".

So far, the Courts have rarely brought judgments related to discrimination at work, and moreover, initially imposed minimum fines that could actually not discourage, but rather encourage discrimination ${ }^{30}$. According to the recent data, it seems that the penal policy is changing, as indicated by much larger fines ${ }^{31}$.

\section{Conclusion}

By adoption of the package of anti-discrimination legislation, Serbia has significantly improved the general legal framework for the protection of equality at work. In addition to judicial protection, the Commissioner for Protection of Equality has also begun to play a very constructive role. Activities in this field in the past few years have also been aided by significant activities of the National

which the facts occurred where, under those rules, such discrimination is not sanctioned under substantive and procedural conditions that render the sanction effective, proportionate and dissuasive. It is for the national court to ascertain whether such is the case regarding the rules at issue in the main proceedings and, if necessary, to interpret the national law as far as possible in light of the wording and the purpose of that directive in order to achieve the result envisaged by it".

${ }_{29}$ Official Gazette of the RS, No. 85/2005, 88/2005, 107/2005, 72/2009, 111/2009, 121/2012, $104 / 2013$.

${ }^{30}$ For example, Municipal and then after the Court of Appeal in Novi Sad (Serbia) have decided that a public company from Novi Sad has to pay the sum of 100,000 dinars (it was at that time about 900 EUR) along with the court expenses to the plaintiff because of discrimination and as reimbursement for pecuniary and non-pecuniary damages for mental distress inflicted by the breach of honour, reputation, freedom and personal rights. It was the case of discrimination based on political affiliation where, in consequence of the leadership change, and after certain period of time, the person was moved to less favourable (lower) position in the working process (December 2004), and then after discharged. During the said period, as stated, he was harassed and subjected to pressures on daily basis and roll calls, he was named "the yellow" (referring to his political orientation). After, the hearing of evidence, the Court has verified the accuracy of the allegations made and brought the said judgment (Municipal Court in Novi Sad, No. P-1-6/2011 of 84 2011, the Court of Appeal GZ. 1-1406/11, 911 2011).

31 For example, in early February 2012, a local company "JAT Airways" was bound to pay more than 3.8 million dinars (about 32,000 Euros) to a pilot A.P. (52), covering material damage, court expenses and interest, related to discrimination based on ethnicity and abuse. The judgment of the High Court in Belgrade of 5 January 2012 is available at the sight of the Court: http://www. bg.vi.sud.rs/lt/ 
Ombudsman ${ }^{32}$, as well as the Provincial Ombudsman (in the Autonomous Province of Vojvodina) ${ }^{33}$, that function as independent institutions for the protection of human rights.

One particular quality of the new regulations on protection of equality in Serbia is a high degree of compliance with the EU and international standards (OUN, SE, ILO). However, at the same time, this is where the shortcomings of discrimination acts arise from, since it often happens that individuals or courts are not capable of implementing rules and regulations related to prohibition of discrimination, mainly due to prejudices and social stereotypes. This does not only require a more stringent application of antidiscrimination regulations, but above all necessitates a higher level of consciousness and tolerance in the general public. As far as the area of labour is concerned, a guided action aimed at cultivation of both consciousness and tolerance should mainly focus on employers, employees and their organisations.

\section{Summary}

In this article the author gives a brief presentation of Serbian antidiscrimination legislation. Serbia has started the process of accession to the European Union, so that gradual harmonisation of Serbian law with EU legal standards is to be expected. Legislation on equality of employees is one of the most developed areas of the law of the European Union. The EU documents on equality of the employees have served as a model used by Serbian legislature. Although many solutions in these acts are based on community standards (e.g. definition of direct and indirect discrimination, harassment, sexual harassment), it is evident that in practice harmonisation of Serbian law is by far inadequate. Many legal norms inspired by the EU standards have not yet been implemented and it is uncertain whether they will ever be applied. The main causes are found in the different mentality, prejudices and stereotypes, formalism in implementation of the law, and unwillingness of employees to accept changes in conduct and attitude at work.

32 This body, which deals with the protection of citizens' rights in relation to state authorities, became operational in 2007. See for more at: http://www.ombudsman.rs/

33 See for more at: http://www.ombudsmanapv.org/apvomb/ 